\title{
Using the Job Demands-Resources Model to Predict Job Satisfaction of Employees in Indonesia
}

\author{
Amirah Widia Adiarti \\ Department of Psychology, Graduate School, Yogyakarta State University \\ widiaadiarti@gmail.com \\ Dimyati \\ Department of Psychology, Graduate School,Yogyakarta State University \\ dimyati@uny.ac.id
}

\begin{abstract}
Although the job demands-resources model (JD-R) is getting much attention in the literature, there is limited, if any, empirical research in Indonesia. This study used the JD-R model to predict job satisfaction in Indonesia with a sample of 17,I77 employees. Using data from the $5^{\text {th }}$ wave of the Indonesian Family Life Survey, Exploratory factor analysis (EFA), confirmatory factor analysis (CFA), and structural equation modeling (SEM) were performed for data analysis. The main findings revealed a positive relationship between job resources and job satisfaction, and a negative relationship between challenging job demands and job satisfaction beyond the contribution of gender, age, education, marital status, and job type. The findings of this study suggest that managers should provide employees with more resources and engage them in crafting behaviors.
\end{abstract}

Keywords: job demands, job resources, job satisfaction, JD-R model, Indonesia

Received 4 March 2021/Accepted 6 June 2021 @Author all rights reserved

\section{Introduction}

Over the past years, organizational psychologists and economists have used the job demands-resources model to predict several outcomes for employees and organizations. For example, job demands and job resources got used to predict burnout of employees and performance of organizations (Bakker, Demerouti, \& Verbeke, 2004) as well as health and wellbeing (Schaufeli, 2017). Other scholars have sought to investigate whether those job characteristics are related to job satisfaction (Yeh, 2015), a measure of life satisfaction of employees. Job satisfaction was stated as a fascinating variable given that it is directly related to quits and absenteeism (Freeman, 1978; Clark \& Oswald, 1996; Hernández-Cantú \& Medina-Campos, 2020), to health and wellbeing, and organizational performance (Aristovnik, Seljak, \& Tomaževič, 2016). Work-related factors got empirical attention in the literature as 
determinants of job satisfaction. Specifically, many researchers have used the job demandsresources model to explain the variations in job satisfaction among employees (Yeh, 20I5; Gazioglu \& Tansel, 2006).

Although the job demands-resources model is increasingly discussed in the literature, there is little empirical research from Indonesia discussing its relation to job satisfaction of employees. One study investigated the psychometric properties of the job demandsresources model of work engagement in Indonesia and found satisfying properties of the model among Indonesian people (Helmi et al., 2020). However, the relation of the model with job satisfaction was not addressed. In another study, it was found that work overload, one of the job demands, was associated with turnover intentions through job satisfaction and work stress (Pradana \& Salehudin, 2015). However, only one indicator of job demands was used, implying the need of using the whole job demands and resources model. Batubara, Syam, and Wahyuni (2020) found also that job demands and resources were related to performance of nurses, but the relation with job satisfaction was not addressed. These studies, although interesting, have used small samples which yields the need of using a national representative sample. Therefore, this study aims to use the job demands-resources model to predict job satisfaction of Indonesian employees using national representative data.

The following section provides a quick overview of the literature followed by a description of the research methods used in section 3. Section 4 presents the study results. Section 5 discusses the findings followed by concluding remarks.

The job demands-resources model (JD-R)

Many scholars contend that even though every occupation has its own work characteristics, these work conditions may be characterized in two wide categories: job demands and job resources (Demerouti, Bakker, Nachreiner, \& Schaufeli, 200I; Bakker et al., 2004). Bakker et al. (2004) define job demands as those physical, psychological, social, and organizational aspects of the job that involve physical and/or psychological (cognitive and emotional) effort which may bring certain physiological and or psychological costs. Examples are high work pressure, work overload, emotional demands (Bakker et al. 2004). 
On the other side, job resources are those physical, psychological, social, and organizational aspects of the job that are fundamental for goal achievement, that reduce job demands and stimulate growth, learning, and development (Bakker et al. 2004; Bakker \& Demerouti, 2007). Examples are salary, carrier opportunities, job security, co-worker support, team climate (Bakker et al. 2004).

Originally, the JD-R model was first used by Demerouti et al. (200I) to understand burnout. They found that job demands are associated with exhaustion of employees, one of the components of burnout, and lack of job resources was associated with disengagement, the other component of burnout. Subsequent studies sought to examine this model for diverse outcomes. Bakker, Demerouti, Boer, and Schaufeli (2003) applied the model on employees of a telecom company to predict absenteeism and the results evidenced a prediction of job demands on health issues which leads to absenteeism on one hand and a prediction of job resources on dedication and organizational commitment. Schaufeli (2017) used the JD-R model to develop a so-called "regulative cycle" guide that can be used by organizations to promote work engagement and decrease burnout. In their longitudinal study, Xanthopoulou, Bakker, Demerouti, and Schaufeli (2009) provided evidence of a reciprocal relationship between job resources and work engagement. Job and personal resources predicted work engagement and work engagement predicted job and personal resources over time.

\section{Job satisfaction}

Job satisfaction as an economic variable was first introduced by Hamermesh (1977) and Freeman (1978) trying to explain factors that make the well-being of employees at work. Job satisfaction can be defined as an affective and cognitive evaluation of the pleasure that an employee derives from his /her job (Hulin \& Judge, 2003) and has multiple implications. In fact, Freeman (1978) states that job satisfaction is as good as wages in predicting quits and absenteeism. On the other side, job satisfaction predicts employee wellbeing and organizational performance (Aristovnik et al., 2016). Consequently, many scholars have therefore sought to investigate the determinants of job satisfaction.

It is legitimate to believe that wages are associated with job satisfaction. Using data from the German Socio-Economic Panel, Grund and Sliwka, (200I) found a positive effect of absolute 
wage and wage increases on job satisfaction. Previously, Clark (1999) found similar results except for the absolute wage whose association with job satisfaction was not significant. Inequality in wages seems to have a deleterious effect on employee's satisfaction with job. Investigating the effect of peer salaries on job satisfaction, Card, Mas, Moretti, and Saez (2012) found that employees earning less than their peers reported low satisfaction with job. Similarly, Clark and Oswald (1996) found that increased peer wage was inversely related to one's job satisfaction. These findings combined indicate the importance of increased wages in determining the wellbeing of employees at the workplace as measured by job satisfaction.

Non-financial job-related factors are as well discussed in the literature as major determinants of job satisfaction. In their longitudinal study, Salvatori (2010) claimed evidence of the type of contract, job quality and job insecurity as determinants of job satisfaction. In their study, employees' wellbeing was inversely correlated with restrictions to temporary employment. Union membership seems to exhibit a negative correlation with job satisfaction as found by Meng (1990) and Hammer \& Avgar (2005). As can be expected, job stress is inversely related to job satisfaction (Spector, Cooper, Poelmans, \& Allen, 2004; Bemana, Moradi, Ghasemi, Taghavi, \& Ghayoor, 20I3; Kumar, 2017). Receiving job training seems to be positively associated with job satisfaction while hours of work exhibit negative association (Gazioglu \& Tansel, 2006). Job security seems to impact job satisfaction of employees. In fact, those who reported that their job is secure are highly more satisfied with it than their counterparts (Gazioglu \& Tansel, 2006)

Demographic and individual variables are found important factors of job satisfaction as well. Concerning gender, for example, females report higher satisfaction compared to males (Clark, 1997; Gazioglu \& Tansel, 2006). In their study on academics of high education, Saner and Eyüpoğlu (2012) found a non-linear relationship of job satisfaction with age, yet indicating high satisfaction for the older while some found a U-shaped relationship (Clark, Oswald, \& Warr, 1996; Gazioglu \& Tansel, 2006) and others a linear positive relationship (Hunt \& Saul, 1975). Mixed findings are reported concerning education and job satisfaction. Some scholars reported a positive linear relationship (Dantzker, 1993) while others found no significant relationship with a sample of police officers (Johnson, 2012; Kumar, 2017). 
Despite the well-known finding that married people are happier in general, Gazioglu \& Tansel (2006) reports that they are less satisfied with their job.

Given these findings from previous studies, 3 hypotheses are proposed in this study: I) the job demands are negatively related to job satisfaction. 2) the job resources are positively related to job satisfaction. 3) job challenges are positively related to job satisfaction.

\section{Method}

The data come from the Indonesian Family Life Survey (IFLS) $5^{\text {th }}$ wave which took place in late 2014 and early 20I5. IFLS is an ongoing longitudinal socioeconomic and health survey that began in 1993 and has already completed 5 rounds and represents around $83 \%$ of the entire Indonesian population (Strauss, Witoelar, \& Sikoki, 2016). It provides data information on individuals, their families, households, communities, education as well as on health. More information can be found in (Strauss et al., 2016). IFLS5 collected information on 16,204 households and 50,148 individuals using multistage stratified sampling (Strauss et al., 2016). Several household members were randomly selected and asked for detailed personal information. In this study, we used the $5^{\text {th }}$ wave as it is the most recent wave available. The sample was restricted to individuals who reported that they are employed. After correcting missing data for job satisfaction, a sample of 17, 177 employees was yielded.

\section{Measures}

Outcome variables. Job satisfaction served as the outcome variable. Job satisfaction was measured by a single question: how satisfied are you with your current job? (Strauss et al., 2016). The answers range between I(very satisfied) and 4 (very unsatisfied) (Strauss et al., 2016). The scores were then reversed so that high scores indicated high satisfaction. The mean score is $2.94(\mathrm{SD}=0.56$, range=1-4). The descriptive statistics are found in the appendix.

Independent variable. The job demands-resources model served as the explanatory variable. The survey asked employees a set of job characteristics questions. Do you work with a 
contract? Are you a member of a labor union or a business association? Have you ever received any training from your employer? Did you receive the following benefits from your employer for this job? (transport allowance, health insurance, pension) (Strauss et al., 2016). All these items have a yes or no option. A dummy code I was given to answers yes and 0 to answers no. The survey asked a set of other job-related questions. Approximately what was your salary/wage during the last month (including the value of all benefits)? This item was dichotomized to be on the same scale as the previous items. A dummy code I was given to a wage over 2,500,000 rupiahs indicating a good wage and a dummy code 0 otherwise. Normally, what is the approximate total number of hours you work per week? (Strauss et al., 2016). A number of hours greater than 40 was given a dummy code I indicating work overload, and a dummy code 0 was given otherwise. The survey asked a set of other jobrelated questions. My job requires intense concentration, my job involves a lot of stress; my job requires lots of physical effort; my job requires lifting heavy loads; my job requires stooping, kneeling, crouching; My job requires good eyesight; My job requires skill in dealing with people; My job requires me to work with computers. The answers to these questions are all/almost all the time, most of the time, some of the time and none/almost none of the time. These items were dichotomized to be on the same scale as the previous ones. Answers all/almost all the time, most of the time, and some of the time were given a dummy code I while none/almost none of the time was given a dummy code 0 .

Statistical analysis. The statistical analysis was carried out with $\mathrm{R}$ statistical software (Fox \& Leanage, 2016). The exploratory factor analysis (EFA) with oblique rotation was carried out with 'psych' package (Revelle, 20I7) and confirmatory factor analysis (CFA) was carried out with 'lavaan' package (Rosseel, 20II). As the job characteristics items are binary, the factor analysis is computed on the tetrachoric correlation matrix (Muthen, 1978). This is possible by using the 'hetcor' function from the 'polycor' package (Fox, 20I4). The CFA is performed using Diagonally Weighted Least Squares (DWLS) estimator (Forero, Maydeuolivares, \& Gallardo-Pujol, 2009). The scree plot is used to determine how many factors to extract. Two potential psychometric models are identified. The two models are subjected to confirmatory factor analysis. Subsequently, fit indices are compared to see which model is better. Finally, structural equation modelling (SEM) is conducted using 'lavaan' package 
(Rosseel, 20II) to predict links between the constructs of job characteristics identified by the final CFA and job satisfaction of employees.

Different parameters are compared to evaluate the EFA, CFA, and SEM model fit (Hu \& Bentler, 1999). Comparative Fit Index (CFI); Tucker Lewis Index (TLI); Root Mean Square Error of Approximation (RMSEA); Standardized Root Square Mean Residual (SRMR). To compare CFA models with different number of factors, indices that are less sensitive to sample size are used (TLI, RMSEA; Sharma, Mukherjee, Kumar, \& Dillon, 2005). Values of 0.95 and above are considered perfect for $\mathrm{CFI}$ and TLI and values of 0.05 or less are perfect for RMSEA.

\section{Results}

The descriptive statistics are found in the appendix. Table I presents the correlations between the 16 items. The exploratory factor analysis showed possible models based on the scree plot. Figure I shows that plausible models are composed of 2 and 3 factors. We agree not to include the four-factor model because it is located at the inflection curve of the scree plot. Most of the factor loadings are acceptable in all models (greater than 0.45) except 3 factor loadings that were below 0.4 (items 4, 10, and 12). These items were then removed.

Confirmatory factor analysis was conducted on the remaining 13 items separately into a two-factor model (factor I: items 1,2,3,5,6,7, 13,14,I5,16; factor 2: items 8,9,II) and a three-factor model (factor I: items 1,2,3,5,6,7; factor 2: items 8,9,II; factor 3: items $13,14,15,16)$. Table 3 shows fit indices for these 2 models. Both models presented excellent CFI and TLI values over 0.95 , and poor RMSEA and SRMR values over 0.05 . The models were then subjected to modification indices and the results showed that the poor fit indices were due to the covariances between items 15 and 16 and between items 6 and 14. These covariances were then included in the models to control for them. 
Table I

Inter-correlations of the items

\begin{tabular}{|c|c|c|c|c|c|c|c|c|}
\hline & $\mathbf{I}$ & 2 & 3 & 4 & 5 & 6 & 7 & 8 \\
\hline I. Income & $1.00 *$ & & & & & & & \\
\hline 2. Union membership & $0.65^{*}$ & $1.00 *$ & & & & & & \\
\hline 3. Health insurance & $0.94 *$ & $0.69 *$ & $1.00 *$ & & & & & \\
\hline 4. Transport allowance & $0.63^{*}$ & 0.31 & $0.62^{*}$ & $1.00 *$ & & & & \\
\hline 5. Pension allowance & $0.94 *$ & $0.72 *$ & $0.97^{*}$ & $0.52^{*}$ & $1.00 *$ & & & \\
\hline 6. Getting training & $0.84^{*}$ & $0.64^{*}$ & $0.82^{*}$ & $0.54^{*}$ & $0.84^{*}$ & $1.00 *$ & & \\
\hline 7. Have a contract & $0.66^{*}$ & $0.43 *$ & $0.73^{*}$ & 0.38 & $0.68^{*}$ & $0.68^{*}$ & $1.00 *$ & \\
\hline 8. Lifting heavy loads & $-0.89 *$ & $-0.59 *$ & $-0.87 *$ & $-0.65 *$ & $-0.80 *$ & $-0.88 *$ & $0.72^{*}$ & $1.00 *$ \\
\hline 9. Requires Physical effort & $-0.82 *$ & -0.48 & $-0.80 *$ & $-0.61 *$ & $-0.77^{*}$ & $-0.72^{*}$ & $-0.62^{*}$ & $0.89 *$ \\
\hline 10. Work overloads & $-0.70^{*}$ & $-0.69 *$ & $-0.66 *$ & -0.43 & $-0.73^{*}$ & $-0.77^{*}$ & $-0.57^{*}$ & $0.61 *$ \\
\hline II. Requires kneeling & $-0.84 *$ & $-0.64 *$ & $-0.83 *$ & $-0.67 *$ & $-0.80 *$ & $-0.82 *$ & $-0.7 \mid *$ & $0.93 *$ \\
\hline 12. Requires good eyesight & -0.12 & 0.02 & -0.15 & -0.26 & -0.08 & -0.01 & -0.13 & 0.11 \\
\hline 13. Involves a lot of stress & 0.30 & 0.07 & 0.24 & 0.23 & 0.24 & 0.44 & 0.24 & -0.40 \\
\hline 14. Working with computers & $0.83^{*}$ & $0.50^{*}$ & $0.76^{*}$ & $0.59 *$ & $0.78^{*}$ & $0.89 *$ & $0.64^{*}$ & $-0.88^{*}$ \\
\hline 15. Dealing with people & 0.44 & 0.30 & 0.37 & 0.28 & 0.38 & $0.57^{*}$ & 0.39 & -0.46 \\
\hline 16. Intense concentration & 0.44 & 0.30 & 0.37 & 0.28 & 0.38 & $0.57^{*}$ & 0.39 & -0.46 \\
\hline
\end{tabular}

The improved models exhibited better model fit; however, the two-factor model still did not reach the desired model fit for RMSEA and SRMR. Therefore, the three-factor model was selected as the best model. The fit indices of the improved models are found in table 3 . The 3 factors were then labeled as follows: factor I was labeled 'job resources', factor 2 was labeled 'hindering job demands', and factor 3 was labeled challenging job demands (Broeck, Cuyper, De, \& Vansteenkiste, 2010). Table 4 displays the loadings of the items on their respective latent variables. Table 2 displays intercorrelation of items. 
Table 2

Inter-correlations of the items

\begin{tabular}{|c|c|c|c|c|c|c|c|c|}
\hline tems & 9 & 10 & II & 12 & 13 & 14 & 15 & 16 \\
\hline \multicolumn{9}{|l|}{ I. Income } \\
\hline \multicolumn{9}{|l|}{ 2. Union membership } \\
\hline \multicolumn{9}{|l|}{ 3. Health insurance } \\
\hline \multicolumn{9}{|l|}{ 4. Transport allowance } \\
\hline \multicolumn{9}{|l|}{ 5. Pension allowance } \\
\hline \multicolumn{9}{|l|}{ 6. Getting training } \\
\hline \multicolumn{9}{|l|}{ 7. Have a contract } \\
\hline \multicolumn{9}{|l|}{ 8. Lifting heavy loads } \\
\hline 9. Requires Physical effort & $1.00 *$ & & & & & & & \\
\hline 10. Work overloads & 0.45 & $1.00 *$ & & & & & & \\
\hline II. Requires kneeling & $0.84 *$ & $0.50 *$ & $1.00 *$ & & & & & \\
\hline 12. Requires good eyesight & 0.22 & -0.11 & 0.20 & $1.00 *$ & & & & \\
\hline 13. Involves a lot of stress & -0.31 & -0.33 & -0.38 & 0.29 & $1.00 *$ & & & \\
\hline 14. Working with computers & $-0.77^{*}$ & $-0.73^{*}$ & $-0.84 *$ & 0.04 & $0.62 *$ & $1.00 *$ & & \\
\hline 15. Dealing with people & -0.34 & $-0.43^{*}$ & -0.46 & 0.40 & $0.62 *$ & $0.72 *$ & $1.00 *$ & \\
\hline 16. Intense concentration & -0.34 & $-0.43^{*}$ & -0.46 & 0.40 & $0.62 *$ & $0.72 *$ & $0.80 *$ & $1.00 *$ \\
\hline
\end{tabular}

Scree plot

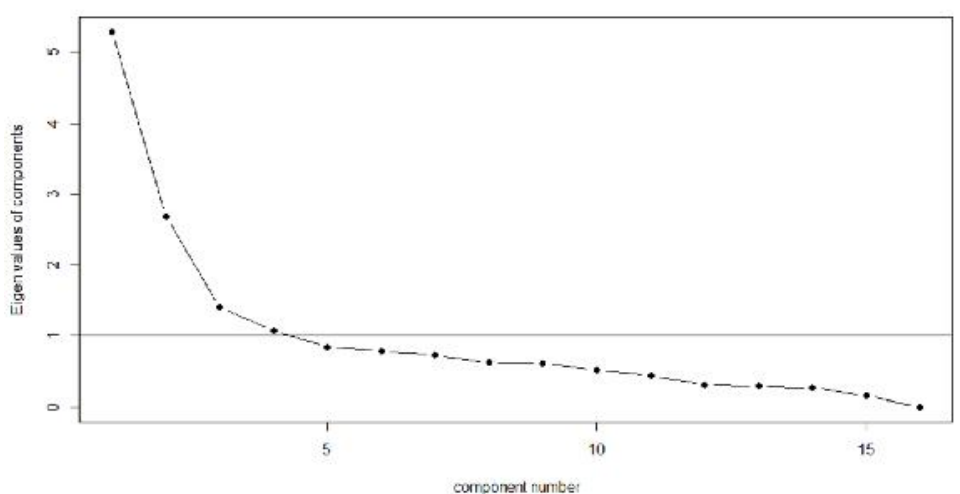

Fig I. EFA scree plot of the 16 items 
Table 3

Fit indices for the CFA models

\begin{tabular}{lllllllll}
\hline & \multicolumn{7}{l}{ Initial Models } & \multicolumn{7}{c}{ Improved models } \\
\hline Models & CFI & TLI & RMSEA & SRMR & CFI & TLI & RMSEA & SRMR \\
$\begin{array}{l}\text { I. Two- } \\
\text { factor }\end{array}$ & 0.98 & 0.98 & 0.09 & 0.16 & 0.99 & 0.99 & 0.06 & 0.09 \\
$\begin{array}{l}\text { 2. Three- } \\
\text { factor }\end{array}$ & 0.98 & 0.98 & 0.06 & 0.10 & 0.99 & 0.99 & 0.05 & 0.07 \\
\hline
\end{tabular}

CFI: Comparative Fit Index; RMSEA: Root Mean Square Error of Approximation; SRMR: Standardized Root Square Mean Residual.

Table 4

Factor loadings of the three-factor model

\begin{tabular}{lc}
\hline Job resources & Factor loadings of the I3 items \\
\hline I. Income & 0.79 \\
2. Union membership & 0.48 \\
3. Health insurance & 0.86 \\
4. Transport allowance & - \\
5. Pension allowance & 0.86 \\
6. Getting training & 0.67 \\
7. Have a contract & 0.5 I \\
Hindering job demands & \\
8. Lifting heavy loads & 0.94 \\
9. Requires physical effort & 0.6 I \\
I0. Work overloads & - \\
II. Requires kneeling & 0.72 \\
Challenging job demands & 0.67 \\
I2. Requires good eyesight & 0.67 \\
I3. Involves a lot of stress & - \\
I4. Working with computers & \\
I5. Dealing with people & \\
I6. Intense concentration & \\
\hline
\end{tabular}


The Job Demands-Resources Model and job satisfaction

In the next stage of the study, Structural Equation Model (SEM) was tested to allow the predictive relationships between job resources, job demands, and job satisfaction. Significant covariates were included in the model (gender, age, education, marital status, job type).

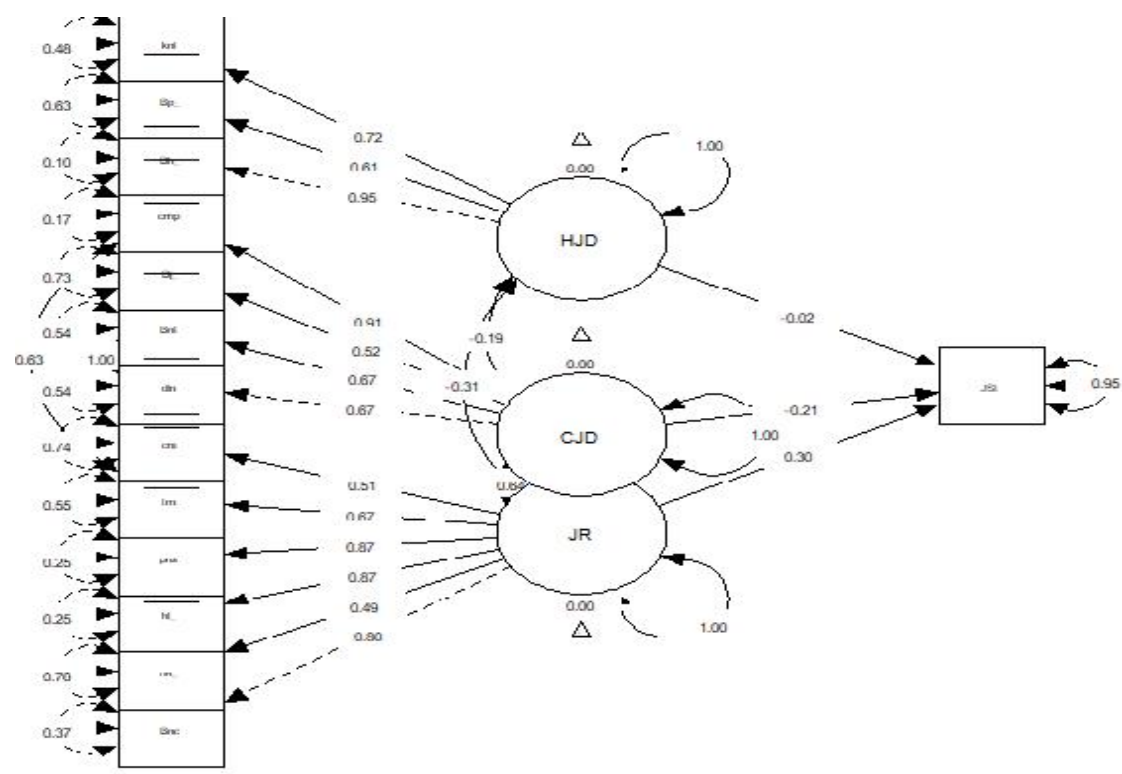

JR: job resources, HJD: hindering job demands, CJD: challenging job demands, JSA: job satisfaction.

Fig 2. Structural model of the relationships between hindering job demands, challenging job demands, job resources, and job satisfaction

The SEM model presented good model fit $(\mathrm{CFI}=0.99, \mathrm{TLI}=0.99, \mathrm{RMSEA}=0.09, \mathrm{SRMR}=$ 0.06). Figure 2 presents the visual results of the SEM model. As expected, job resources significantly predicted job satisfaction $(\beta=0.30, \rho<0.01)$. An increase in job resources leads to an increase in job satisfaction. Likewise, challenging job demands significantly predicted job satisfaction. However, while we would expect that increases in job challenges would increase job satisfaction, we found that increases in job challenges are associated with a decrease in job satisfaction $(\beta=-0.21, \rho<0.01)$. Though hindering job demands exhibited a negative association with job satisfaction, it was not statistically significant. 


\section{Discussion}

The purpose of this study was to examine the job demands-resources model in Indonesia. Using data from the Indonesian Family Life Survey, the results support the multidimensionality nature of job characteristics, job resources and job demands (Demerouti et al., 200I). Moreover, the results support the theory that all job demands are not the same, differentiating between challenging job demands and hindering job demands (Broeck et al., 2010). Specifically, getting a good income, training, health insurance, getting pension allowance, being a labor union member converged into job resources; lifting heavy loads, having a job that requires physical effort and kneeling or stooping converged into hindering job demands; having a job that requires intense concentration, good eyesight, dealing with people, working with computers, and involves a lot of stress converged into challenging job demands. The tripartite model presented better model fit.

While we would expect a moderate positive correlation between hindering job demands and challenging job demands as they share some features, they displayed a small but negative correlation. This shows that they are somewhat distinct. Challenging job demands and job resources shared a moderate but positive correlation, probably because they share stimulating features (Broeck et al., 2010). Hindering job demands and job resources exhibited a moderate negative correlation. This may be explained by the fact that job hindrances impact negatively on job resources as postulated by the Conservation of Resources Theory (Hobfoll, 2002). This theory posits that employees are more affected by resources loss than resources gain and that this presents a risk for burnout.

As expected, job resources predict job satisfaction. Getting benefits from the employer contributes to the satisfaction of employees. This is in line with previous studies that found a positive effect of job resources on job satisfaction of employees in East Asia (Yeh, 20I5) and in Europe (Sousa-poza \& Sousa-Poza, 2000). Moreover, job resources were found predictive of some other positive outcomes such as work engagement and intrinsic work motivation (Schaufeli, Bakker, \& Rhenen, 2009). Job resources may act as an extra motivation to the workers which might explain the positive relationship.

While others have found that challenging job demands positively relate to outcomes such as vigor (Broeck et al., 2010), this study found a negative association of challenging job 
demands with job satisfaction in Indonesia. Employees with increased job challenges would have decreased satisfaction with their job in the end. It seems that the job challenges have an energy-depleting effect which leads to dissatisfaction with one's job. Job challenges were also previously found to positively relate to burnout in a meta-analytic study (Crawford, Lepine, \& Rich, 2010). It is possible that job challenges bring positive outcomes when they are well surmounted and turned into an advantage. Let's take an example of the job challenges used in this study. An employee whose job requires intense attention and concentration may feel exhausted over time. However, if they learn how to handle or organize this concentration in a playful way, they may turn it into personal growth. Tims, Bakker, and Derks (2013) call this job crafting, which consists of modifying aspects of one's job characteristics to fit with their needs and ability. In their longitudinal study, they found that crafting challenging job demands led to increases in employees' well-being.

Hindering job demands did not exhibit a significant relationship with job satisfaction. This is probably because the hindering job demands items used in this study are specific to particular occupations. Lifting heavy loads, jobs that require physical effort, kneeling, or snooping are mostly found in agriculture and related sectors. Previous studies found a negative and significant association between job demands and job satisfaction (Yeh, 20I5). Other scholars have reported negative impacts of job demands on health which might lead to absenteeism (Bakker et al., 2003).

The study results have several managerial implications. First, the job demands-resources model seems to predict job satisfaction of employees, therefore, the model should get much more attention in Indonesia and in South East Asia. The model has been shown to yield positive outcomes in different part of the world (Bakker et al. 2004; Gazioglu \& Tansel, 2006). Second, the survey used in this study contains limited job characteristics items. Future waves of the survey should include questions that are currently used and tested in the literature. This is a call to survey conductors in South East Asia to include questions about job demands and job resources and work-related factors such as dedication, vigor, burnout, engagement, and managerial leadership. This concerns national and/or regional surveys. It is important to monitor organizational performance through job characteristics at the workplace having in mind that a satisfied worker will perform well individually and in team. Third, managers and team leaders should be aware that increasing job resources leads 
to increases in job satisfaction, which in turn might lead to organizational performance (Bakker et al., 2004). It is the task of employers to provide job resources to their employees. Fourth, it seems that challenging job demands have a deleterious effect on job satisfaction in Indonesia, managers should find strategies to allow employees to craft these job demands for a better outcome. Fifth, employees should learn how to craft their job demands and resources themselves to create an engaging atmosphere at work. It has been demonstrated that employees who had crafted their job characteristics to fit in their ability, had positive outcomes (Tims, Bakker, \& Derks 20I3).

This study has contributed to the literature by providing an empirical evidence of the association between the job demands-resources model in Indonesia. To the best of our knowledge, this is the first study to so. In addition, it was found in this study that challenging job demands had a negative association with job satisfaction while other studies found a positive association. It is interesting to investigate this issue further and future research in Indonesia and in South East Asia should consider explaining this issue. Some limitations need to be acknowledged. First, although the data used have a national scope, they are crosssectional. Therefore, no causation can be made. Future researches should use longitudinal designs. Second, the job demands and job resources items used in this study differed a lot from those currently used in the literature. This may lead to inaccurate results. Third, the items were binary, which is not ideal for factor analysis although advances have been made in statistical tools to handle this.

\section{Conclusion}

The paper has found a positive association between job resources and job satisfaction, and a negative association between challenging job demands and job satisfaction. It has been argued that the negative association may be due to the lack of crafting behaviors among employees. Job resources and engaging in job crafting behaviors are key elements of job satisfaction and consequently of organizational performance. 


\section{Acknowledgment}

We used data from the Indonesian Family Life Survey, we are grateful to the RAND Organization who provided free access to the data. We are also grateful to the Indonesian respondents who answered the survey.

\section{References}

Aristovnik, A., Seljak, J., \& Tomaževič, N. (2016). A three-stage data envelopment analysis approach to measure the effect of job satisfaction on organisational performance in law enforcement agencies. International Journal of Services and Operations Management, 25(3). https://doi.org/I0.I504/IJSOM.2016.10000240

Bakker, A. B., \& Demerouti, E. (2007). The job demands-resources model : State of the art. Journal of Managerial Psychology, 22(3), 309-328. https://doi.org/I0.1 108/026839407/0733II5

Bakker, A. B., Demerouti, E., Boer, E. De, \& Schaufeli, W. B. (2003). Job demands and job resources as predictors of absence duration and frequency. Journal of Vocational Behavior, 62, 34I-356. https://doi.org/I0.1016/S000I-879I(02)00030-I

Bakker, A. B., Demerouti, E., \& Verbeke, W. (2004). Using the job demands-resources model to predict burnout and performance. Human Resource Management, 43(I), 83104. https://doi.org// 0.1002/hrm.84

Batubara, K., Syam, B., \& Wahyuni, S. E. (2020). Job demands-resources model affects the performance of associate nurses in hospital. Jurnal Keperawatan Indonesia, 23(2), I I II I8. https://doi.org/I0.7454/jki.v23i2. II 32

Bemana, S., Moradi, H., Ghasemi, M., Taghavi, S. M., \& Ghayoor, A. H. (20I3). The relationship among job stress and job satisfaction in municipality personnel in Iran Faculty of Azad university. World Applied Sciences Journal, 22(2), 233-238. https://doi.org/I0.5829/idosi.wasj.20I3.22.02.3640

Broeck, A. Van Den, Cuyper, N. De, De, H., \& Vansteenkiste, M. (2010). Not all job demands are equal: Differentiating job hindrances and job challenges in the job demands - resources model. European Journal of Work and Organizational Psychology, 19(6), 735-759. https://doi.org//0.1080/I3594320903223839

Card, B. D., Mas, A., Moretti, E., \& Saez, E. (20I2). Inequality at work: The effect of peer salaries on job satisfaction. American Economic Review 2012,102(6), 298I-3003.

Clark, A. E. (1997). Job satisfaction and gender: Why are women so happy at work? Labour Economics, 4, 34I-372.

Clark, A. E. (1999). Are wages habit-forming ? Evidence from micro data. Journal of Economic Behavior \& Organization, 39, 179-200.

Clark, A. E., \& Oswald, A. J. (1996). Satisfaction and comparison income. Journal of Public 
Economics, 6I, 359-38I.

Clark, A., Oswald, A., \& Warr, P. (1996). Is job satisfaction U-shaped in age ? Journal of Occupational and Organizational Psychology, 69, 57-8I.

Crawford, E. R., Lepine, J. A., \& Rich, B. L. (2010). Linking job demands and resources to employee engagement and burnout: $A$ theoretical extension and meta-analytic test. Journal of Applied Psychology, 95(5), 834-848. https://doi.org/I0.1037/a0019364

Dantzker, M. L. (1993). Issue for policing: Educational level and job satisfaction: A research note. American Journal of Police, I2(2), 20I-20I8.

Demerouti, E., Bakker, A. B., Nachreiner, F., \& Schaufeli, W. B. (200I). The job demandsresources model of burnout. Journal of Applied Psychology, 86(3), 499-5I 2. https://doi.org/ | 0.1037//002 I-9010.86.3.499

Forero, C. G., Maydeu-olivares, A., \& Gallardo-Pujol, D. (2009). Factor analysis with ordinal indicators : A Monte Carlo study comparing DWLS and ULS estimation. Structural Equation Modeling: A Multidisciplinary Journal, I6(4), 625-64I. https://doi.org//0.1080/10705510903203573

Fox, J. (20I4). The 'polycor' package. Retrieved from http://cran.rproject.org/web/packages/polycor/index.html

Fox, J., \& Leanage, A. (2016). R and the journal of statistical software. Journal of Statistical Software, 73(2). https://doi.org/I0.18637/jss.v073.i02

Freeman, R. B. (1978). Job satisfaction as an economic variable (No. 225). Cambridge, Massachusetts.

Gazioglu, S., \& Tansel, A. (2006). Job satisfaction in Britain: Individual and job related factors. Applied Economics, 38, I I63-II7I. https://doi.org/I0.1080/00036840500392987

grund, c., \& sliwka, d. (200I). The impact of wage increases on job satisfaction - empirical evidence and theoretical implications (No. 387). Bonn.

Hamermesh, D. S. (1977). Economic aspects of job satisfaction. Essays in labor market analysis. New York: John Wiley.

Hammer, T. H., \& Avgar, A. (2005). The impact of unions on job satisfaction, organizational commitment , and turnover. Journal of Labor Research, 26(2). https://doi.org/I0.1007/s I 2122-005-1024-2

Helmi, A. F., Widhiarso, W., Marvianto, R. D., Priwati, A. R., Mustari, M. A., \& Artikasari, Y. $V$. (2020). The Fourth dimensions of the job demands-resources (JD-R) model of work engagement in Indonesian context. Jurnal Psikologi, 47(3), 206.

https://doi.org// 0.22 I46/jpsi.56682

Hernández-Cantú, E. I., \& Medina-Campos, X. L. (2020). Job satisfaction and absenteeism in nurses of a public hospital in Monterrey. Rev. Enferm. Inst. Mex. Seguro Soc, 28(I), 3748.

Hobfoll, S. E. (2002). Social and psychological resources and adaptation. Review of General Psychology, 6(4), 307-324. https://doi.org//0.1037///089-2680.6.4.307 
Hu, L., \& Bentler, P. M. (1999). Cutoff criteria for fit indexes in covariance structure analysis : conventional criteria versus new alternatives. Structural Equation Modeling, 6, I-55. https://doi.org// 0.1080/107055I9909540I I8

Hulin, C. ., \& Judge, T. . (2003). Job attitudes. In W. . Borman, D. . Ilgen, \& R. . Klimoski (Eds.), Handbook of Psychology (Vol. I2): Industrial and Organizational Psychology (pp. 255276). https://doi.org/I0.13189/saj.2019.070202

Hunt, J. W., \& Saul, P. N. (1975). The relationship of age, tenure, and job satisfaction in males and females. Academy of Management, I8(4), 690-702.

Johnson, R. R. (20I2). Police officer job satisfaction: A multidimensional analysis. Police Quarterly, I5(I57). https://doi.org/I0.1 I77/10986 I I I 2442809

Kumar, T. K. V. (20I7). Factors impacting job satisfaction among police personnel in india : a Multidimensional analysis. International Criminal Justice Review, I-23. https://doi.org/10.1 I77//0575677/6683776

Meng, R. (1990). The relationship between unions and job satisfaction. Applied Economics, 22(I2), I635-1648. https://doi.org//0.1080/00036849000000070

Muthen, B. (1978). Contributions to factor analysis of dichotomous variables. Psychometrika, 43(4).

Pradana, A., \& Salehudin, I. (20I5). Work overload and turnover intention of junior auditors in greater Jakarta, Indonesia. The South East Asian Journal of Management, 9(2), 108-124. https://doi.org//0.21002/seam.v9i2.4950

Revelle, W. (2017). Using the psych package to generate and test structural models. Retrieved from https://personality-project.org/r/psych_for_sem.pdf

Rosseel, Y. (20II). lavaan : an R package for structural equation modeling and more Version 0 . 5-IO ( BETA ). Retrieved from http://users.ugent.be/ yrosseel/lavaan/lavaan Introduction.pdf

Salvatori, A. (2010). Labour contract regulations and workers' wellbeing: International longitudinal evidence. Labour Economics, I7(4), 667-678. https://doi.org/10.1016/j.labeco.2010.01.003

Saner, T., \& Eyüpoğlu, Ș. Z. (20I2). The age and job satisfaction relationship in higher education. Procedia - Social and Behavioral Sciences, 55, 1020-1026. https://doi.org//0.1016/j.sbspro.2012.09.593

Schaufeli, W. B. (20|7). Applying the job demands-resources model : A ' how to' guide to measuring and tackling work engagement and burnout. Organizational Dynamics, 46(2), 120-132. https://doi.org/10.1016/j.orgdyn.2017.04.008

Schaufeli, W. B., Bakker, A. B., \& Rhenen, W. V. A. N. (2009). How changes in job demands and resources predict burnout, work engagement, and sickness absenteeism. Journal of Organizational Behavior, 30, 893-917. https://doi.org//0.1002/job.595

Sharma, S., Mukherjee, S., Kumar, A., \& Dillon, W. R. (2005). a Simulation study to investigate the use of cutoff values for assessing model fit in covariance structure 
models. Journal of Business Research, 58, 935-943.

https://doi.org/10.1016/j.jbusres.2003.10.007

Sousa-poza, A., \& Sousa-Poza, A. A. (2000). Well-being at work: a Cross-sational analysis of the levels and determinants of job satisfaction. Journal of Socio-Economics, 29, 517-538. https://doi.org/I0.1016/S1053-5357(00)00085-8

Spector, P. E., Cooper, C. L., Poelmans, S., \& Allen, T. D. (2004). A cross-national comparative study of work-family stressors, working hours, and well-being: China and Latin America versus the Anglo World. Personnel Psychology, 57(I), II9-142.

Strauss, J., Witoelar, F., \& Sikoki, B. (2016). User's Guide for the Indonesia Family Life Survey, Wave 5 (Vol. 2). Retrieved from https://www.rand.org/pubs/working_papers/WRI I43z2.html.

Tims, M., Bakker, A. B., \& Derks, D. (20I3). The impact of job crafting on job demands , job resources, and well-being. Journal of Occupational Health Psychology, I8(2), 230-240. https://doi.org//0.1037/a0032/4 I

Xanthopoulou, D., Bakker, A. B., Demerouti, E., \& Schaufeli, W. B. (2009). Reciprocal relationships between job resources, personal resources, and work engagement. Journal of Vocational Behavior, 74(3), 235-244. https://doi.org/I0.1016/j.jvb.2008.II.003

Yeh, H.-J. (2015). Job demands, job resources, and job satisfaction in East Asia. Social Indicators Research, I2 I, 47-60. https://doi.org/I0.1007/s I I205-0 I4-063 I-9 


\section{Appendices}

$\begin{array}{llll}\text { Variables } & \begin{array}{l}\% / \text { Mean } \\ (S D)\end{array} & \text { Job satisfaction Mean (SD) } & \text { Range } \\ \text { Job satisfaction } & 2.95(0.56) & \mathrm{I}-4 \\ \text { Age } & 39(12.84) & 18-90\end{array}$

Gender

$\begin{array}{llll}\text { Male } & 62.87 & 2.92(0.58) & \mathrm{I}-4 \\ \text { Female } & 37.13 & 2.99(0.5 \mathrm{I}) & \mathrm{I}-4\end{array}$

Education

$\begin{array}{llll}\begin{array}{lll}\text { Elementary } \\ \text { school }\end{array} & 37 & 2.96(0.56) & \mathrm{I}-4 \\ \begin{array}{l}\text { Junior high school } \\ \begin{array}{l}\text { Senior high } \\ \text { school }\end{array}\end{array} & 22.6 & 2.94(0.55) & \mathrm{I}-4 \\ \text { High education } & 35.4 & 2.92(0.57) & \mathrm{I}-4 \\ & 5 & 2.95(0.53 & \mathrm{I}-4\end{array}$

Marital status

$\begin{array}{lccc}\text { Married } & 79.6 & 2.96(0.55) & \mathrm{I}-4 \\ \text { Unmarried } & 20.4 & 2.9 \mathrm{I}(0.58) & \mathrm{I}-4\end{array}$

Good income

$\begin{array}{cccc}\text { Yes } & 22.5 & 3.06(0.52) & \mathrm{I}-4 \\ \text { No } & 77.5 & 2.90(0.57) & \mathrm{I}-4\end{array}$

Union membership

$\begin{array}{lccc}\text { Yes } & 10.3 & 3.04(0.54) & \mathrm{I}-4 \\ \text { No } & 89.7 & 2.94(0.56) & \mathrm{I}-4\end{array}$

Health insurance

$\begin{array}{llcc}\text { Yes } & 29.3 & 3.03(0.52) & \mathrm{I}-4 \\ \text { No } & 70.7 & 2.90(0.58) & \mathrm{I}-4\end{array}$

Transport allowance

$\begin{array}{llll}\text { Yes } & 15.7 & 2.99(0.55) & \mathrm{I}-4 \\ \text { No } & 84.3 & 2.93(0.57) & \mathrm{I}-4\end{array}$

Pension allowance

$\begin{array}{llll}\text { Yes } & 17 & 3.09(0.50) & \mathrm{I}-4 \\ \text { No } & 83 & 2.90(0.57) & \mathrm{I}-4\end{array}$

Getting training 


$\begin{array}{llll}\text { Yes } & 35.5 & 3.02(0.54) & 1-4 \\ \text { No } & 64.5 & 2.92(0.56) & 1-4\end{array}$

Have a contract

$\begin{array}{lccc}\text { Yes } & 24.5 & 2.99(0.55) & \mathrm{I}-4 \\ \text { No } & 75.5 & 2.92(0.57) & \mathrm{I}-4\end{array}$

Lifting heavy loads

$\begin{array}{llll}\text { Yes } & 58.5 & 2.93(0.57) & 1-4 \\ \text { No } & 41.5 & 2.98(0.54) & 1-4\end{array}$

Requires physical effort

$\begin{array}{llll}\text { Yes } & 83 & 2.94(0.56) & \mathrm{I}-4 \\ \text { No } & 17 & 2.97(0.54) & \mathrm{I}-4\end{array}$

Work overloads

$\begin{array}{llll}\text { Yes } & 52 & 2.95(0.55) & \mathrm{I}-4 \\ \text { No } & 48 & 2.94(0.56) & \mathrm{I}-4\end{array}$

Requires good eyesight

$\begin{array}{llll}\text { Yes } & 80 & 2.94(0.56) & \mathrm{I}-4 \\ \text { No } & 20 & 2.96(0.54) & \mathrm{I}-4\end{array}$

Involves a lot of stress

$\begin{array}{llll}\text { Yes } & 39 & 2.89(0.58) & 1-4 \\ \text { No } & 61 & 2.98(0.54) & 1-4\end{array}$

Working with computers

$\begin{array}{llll}\text { Yes } & 18.6 & 2.98(0.55) & \mathrm{I}-4 \\ \text { No } & 81.4 & 2.94(0.56) & \mathrm{I}-4\end{array}$

Dealing with people

$\begin{array}{llll}\text { Yes } & 82 & 2.95(0.55) & 1-4 \\ \text { No } & 18 & 2.92(0.59) & 1-4\end{array}$

Intense concentration

$\begin{array}{llll}\text { Yes } & 82 & 2.95(0.55) & 1-4 \\ \text { No } & 18 & 2.92(0.59) & 1-4\end{array}$

Job satisfaction Mean(SD) = mean and standard deviation of job satisfaction per category 